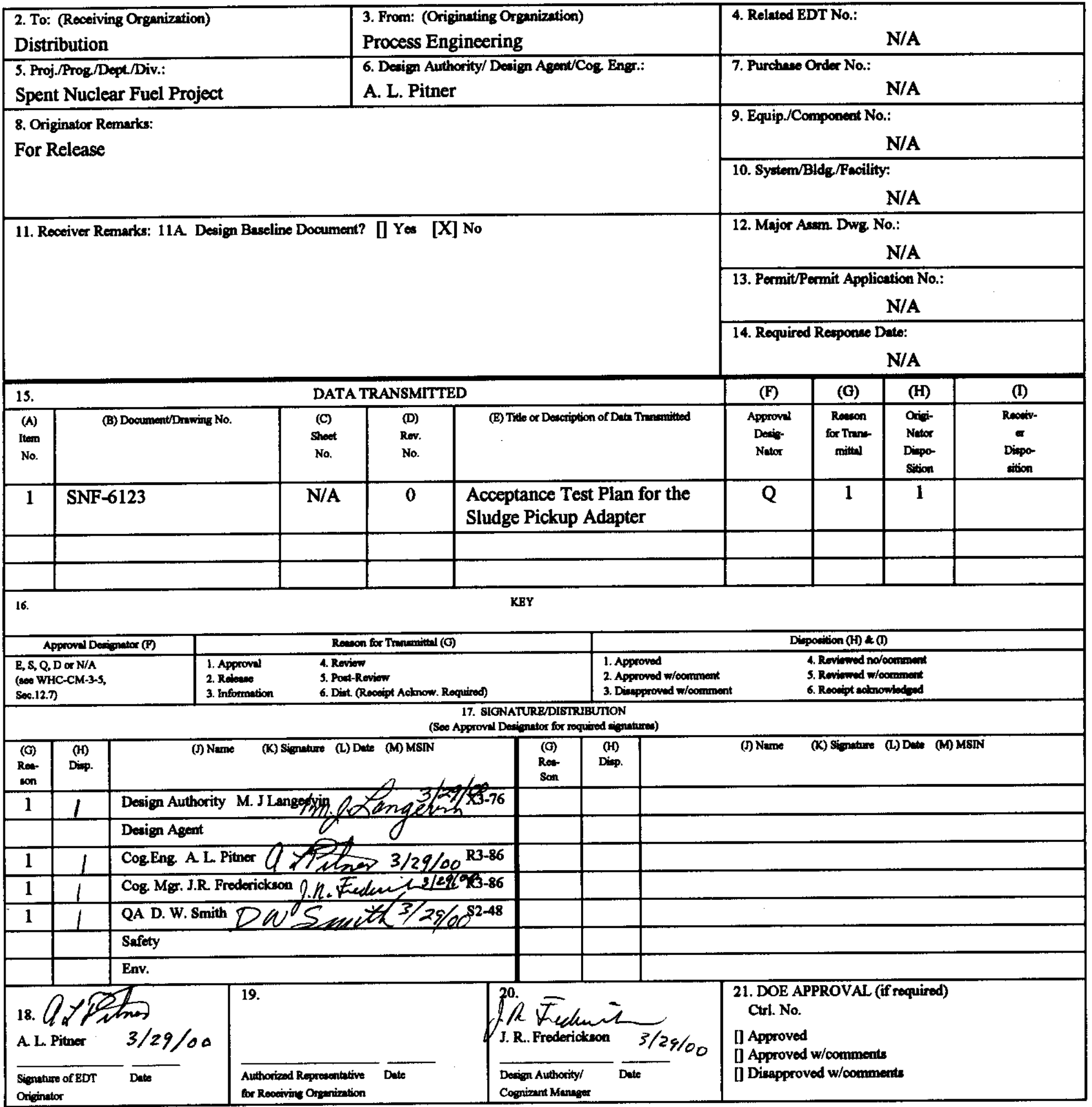

BD-7400-172-2 (05/96) GEF097 
SNF-6123

Revision 0

\section{Acceptance Test Plan for the Sludge Pickup Adapter}

Prepared for the U.S. Department of Energy

Assistant Secretary for Environmental Management

Project Hanford Management Contractor for the

U.S. Department of Energy under Contract DE-AC06-86RL13200

Fluor Hanford

P.O. Box 1000

Richland, Washington 


\section{TRADEMARK DISCLAMMER}

Reference herein to any specific commerclal product, proceas, or service by trade name, trademark, manufacturer, or otherwise, does not necessarlly conetitute or Imply its endoreement, recommendation, or favoring by the United States Government or any agency thereof or its contractors or subcontractors.

This report has been reproduced from the beet available copy. Available in paper copy and microfiche.

Avallable electronically at http://Www.doe gov/bridge. Available for a proceseing foe to the U.S. Department of Energy and lis contractors, in paper, from:

U.S. Department of Energy

Office of Scientific and Technical Information

P.O. Box 62

Oak Ridge, TN 37831-0062

phone: 865-576-8401

fax: 865-576-5728

email: reports Qadonis.osti.gov(423) 576-8401

Printed in the United States of Amorice

Total Pages: 


\title{
Acceptance Test Plan for the Sludge Pickup Adapter
}

\author{
A. L. Pitner \\ Fluor Hanford \\ Date Published \\ March 2000
}

Prepared for the U.S. Department of Energy

Assistant Secretary for Environmental Management

Project Hanford Management Contractor for the

U.S. Department of Energy under Contract DE-AC06-96RL13200

Fluor Hanford

P.O. Box 1000

Richland, Washington

Total pages 6
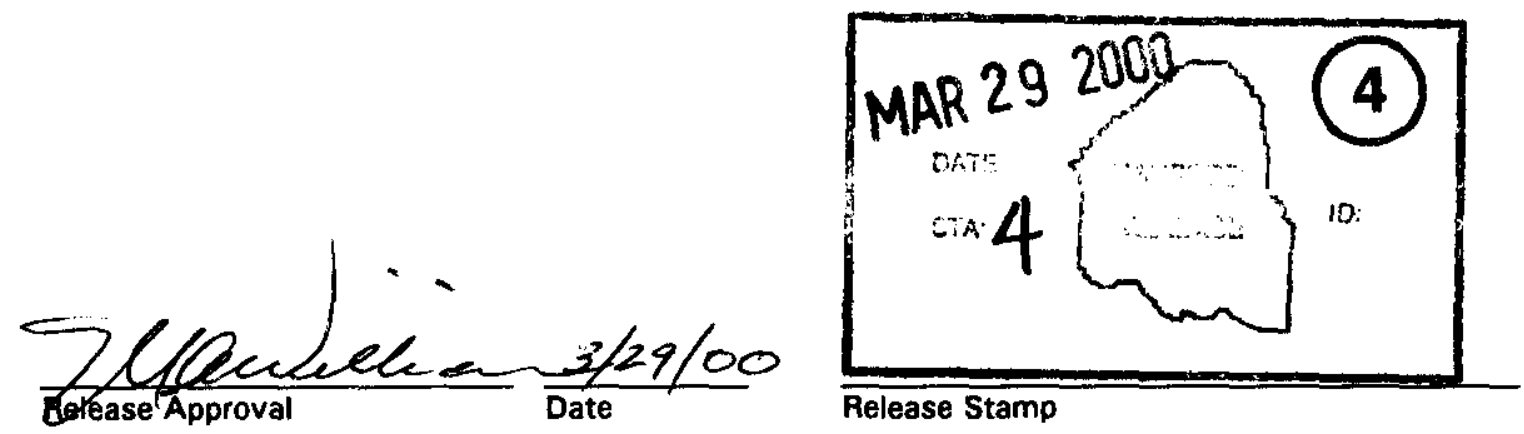


\section{ACCEPTANCE TEST PLAN FOR THE SLUDGE PICKUP ADAPTER}

\subsection{INTRODUCTION}

This test plan documents the acceptance testing of the sludge pickup adapter for potential use during PSI Phases 3 and 4 fuel cleanliness inspection activities. The adapter is attached to the strainer tip of the vacuum wand and used to suction up residual sludge captured in a sludge collection tray. The material is vacuumed into a chamber of known volume in the sludge pickup adapter. The device serves as an aid in helping to determine whether the observed quantity of sludge is within allowable limits $\left(1.4 \mathrm{~cm}^{3}\right.$ per fuel assembly).

This functionality test involves underwater testing in the $\mathbf{3 0 5}$ Building Cold Test Facility to verify that sludge can be successfully vacuumed from a collection tray. Ancillary activities in this acceptance test include demonstration that the sludge pickup adapter can be successfully attached to and detached from the vacuum wand underwater.

\subsection{EQUIPMENT LIST}

The following equipment and materials shall be available to perform the acceptance test.

- Prototype vacuum wand

- Pump capable of providing a flow rate of $80 \pm 10 \mathrm{gpm}$ (calibration not required)

- Underwater camera

- Sludge pickup adapter

- Sludge collection tray with fixture for capturing sludge sample

- Adapter installation fixture

- Sludge simulant (standard mixture of sand, flyash, and tungsten powder)

Test Engineer

Cognizant Engineer

Operations

Quality Assurance 
SNF-6123, Rev. 0

\subsection{PRETEST REQUIREMENTS}

The following requirements shall be verified prior to conducting the acceptance test.

- This test procedure package is marked TEST CONTROL COPY

- All applicable JHAs and MSDSs are posted or located in the test area (Attachment 1)

- Equipment is installed or available for installation at the test area

- Test materials are available at the test area

- Facility support systems are available at the test area

- The pre-job briefing is complete (Attachment 2)

Test Engineer

Cognizant Engineer

Operations

Quality Assurance

\subsection{PROCEDURE}

4.1 Preload the sludge capture fixture in the sludge collection tray with a measured $1.4 \mathrm{~cm}^{3}$ of sludge simulant.

4.2 Fill the sludge capture fixture with water and lower the collection tray to the bottom of the water basin.

4.3 Lower the sludge pickup adapter into the water basin and position in the adapter installation fixture.

4.4 Push the vacuum wand down into the sludge pickup adapter to affix it to the end of the wand. Record the approximate total time to complete Steps 4.3 and 4.4 .

Elapsed time for installing adapter on wand minutes

4.5 Activate the pump and adjust the flow rate to $80 \pm 10 \mathrm{gpm}$.

Flow rate gpm

4.6 Expose the sludge sample in the collection tray by opening the capture fixture. 
4.7 Vacuum the sludge sample from the tray until completely collected or until the adapter plugs and ceases to vacuum any more material. Estimate the total amount vacuumed up by visually observing the quantity remaining in the collection tray and inspecting the surface of the filter in the sludge pickup adapter. The acceptance criterion is that at least $75 \%$ of the starting $1.4 \mathrm{~cm}^{3}$ volume of sludge simulant is estimated to have been vacuumed up.

Estimated amount of material vacuumed up $\%$

4.8 Turn off the pump.

4.9 Detach the sludge pickup adapter from the vacuum wand using the detachment feature on the adapter installation fixture. Record the approximate time required to detach the adapter from the wand.

Elapsed time for detaching adapter from wand minutes

\subsection{VERIFICATION}

The following approvals attest that the above procedural steps were successfully executed and satisfactorily completed.

Test Engineer

Cognizant Engineer

Operations

Quality Assurance 
SNF-6123, Rev. 0

ATTACHMENT 1

JOB HAZARD ANALYSIS AND MATERIAL SAFETY DATA SHEETS

The following JHAs and MSDSs are posted in the test area.

\begin{tabular}{|l|l|l|}
\hline Number & \multicolumn{1}{|c|}{ Title } & Date \\
\hline & & \\
\hline & & \\
\hline & & \\
\hline & & \\
\hline & & \\
\hline & & \\
\hline & & \\
\hline
\end{tabular}


SNF-6123, Rev. 0

ATTACHMENT 2

PRE-JOB BRIEFING SIGNOFF SHEET

\begin{tabular}{|c|c|c|c|}
\hline Printed Name & Signature & Title & Date \\
\hline & & & \\
\hline & & & \\
\hline & & & \\
\hline & & & \\
\hline & & & \\
\hline & & & \\
\hline & & & \\
\hline & & & \\
\hline & & & \\
\hline & & & \\
\hline & & & \\
\hline & & & \\
\hline & & & \\
\hline & & & \\
\hline & & & \\
\hline & & & \\
\hline & & & \\
\hline & & & \\
\hline
\end{tabular}




\begin{tabular}{|c|c|c|c|c|c|}
\hline \multicolumn{6}{|c|}{ DISTRIBUTION SHEET } \\
\hline \multirow{2}{*}{$\begin{array}{l}\text { To } \\
\text { Distribution }\end{array}$} & \multirow{2}{*}{\multicolumn{3}{|c|}{$\begin{array}{l}\text { From } \\
\text { Process Engineering }\end{array}$}} & \multicolumn{2}{|l|}{ Page 1 of 1} \\
\hline & & & & \multicolumn{2}{|l|}{ Date $3 / 29 / 00$} \\
\hline \multicolumn{4}{|c|}{ Project Title/Work Order } & \multicolumn{2}{|c|}{ EDT No. 629013} \\
\hline \multicolumn{4}{|c|}{ Acceptance Test Plan for the Sludge Pickup Adapter } & ECN No. N/A & \\
\hline Name & MSIN & $\begin{array}{l}\text { Text } \\
\text { With All } \\
\text { Attach. }\end{array}$ & $\begin{array}{l}\text { Text } \\
\text { Only }\end{array}$ & $\begin{array}{l}\text { Attach./ } \\
\text { Appendix } \\
\text { Only }\end{array}$ & $\begin{array}{c}\text { EDT/ECN } \\
\text { Only }\end{array}$ \\
\hline
\end{tabular}

Spent Nuclear Fuel Project

G. M. Davis

J. A. Dent

J. R. Frederickson

V. L. Hoefer

R. A. Kaye

M. J. Langevin

W. C. Miller

J. W. Neskas

J. W. Oliver

A. L. Pajunen

A. L. Pitner

M. J. Schliebe

R. A. Sexton

J. L. Shelor

D. W. Smith

G. E. Stegen

J. A. Swenson

J. A. Tittle

P. A. Young

SNF Project

SNF Training

SNF Procedures

$\begin{array}{ll}\text { X3-80 } & \text { X } \\ \text { X3-65 } & \text { X } \\ \text { R3-86 } & \text { X } \\ \text { R3-86 } & \text { X } \\ \text { X3-78 } & \text { X } \\ \text { X3-76 } & \text { X } \\ \text { R3-11 } & \text { X } \\ \text { R3-86 } & \text { X } \\ \text { L6-13 } & \text { X } \\ \text { R3-86 } & \text { X } \\ \text { R3-86 } & \text { X } \\ \text { L6-13 } & \text { X } \\ \text { R3-86 } & \text { X } \\ \text { X3-71 } & \text { X } \\ \text { S2-48 } & \text { X } \\ \text { X3-76 } & \text { X } \\ \text { R3-11 } & \text { X } \\ \text { X3-80 } & \text { X } \\ \text { X3-88 } & \text { X } \\ \text { R3-11 } & \text { X } \\ \text { S2-45 } & \text { X } \\ \text { X3-86 } & \text { X }\end{array}$

